\title{
Creating Opportunities for a Creative Industry Through Screen Printing Learning for Community During the Covid-19 Pandemic
}

\author{
Warli Haryana* \\ Universitas Pendidikan Indonesia \\ Bandung, Indonesia \\ *warliharyana@upi.edu
}

\begin{abstract}
This This study discusses screen printing learning for the creative industry. The goal is to equip the public with skills that can create business opportunities during the Covid-19 pandemic. The benefits of this activity are as a model for entrepreneurship learning and screen printing training, especially for adolescents and communities in Pasirnajung Village, Cimanggung District, Sumedang Regency, West Java Province. The method used is Blended Learning, with the aim that the learning process is effective, communicative and the interaction between trainers and training participants can continue. Learning materials can be delivered in the form of interactive videos, presentation materials, pdf data modules, WhatsApp Group, e-mail, and YouTube. The results of this study indicate the realization of screen printing technical skills that inspire the younger generation and society in creating new business opportunities.
\end{abstract}

keywords-blended learning, creative industry, screen printing, entrepreneurship

\section{INTRODUCTION}

This research result-based community service was carried out in the community of Puteraco RW 03, Pasirnanjung Village, Cimanggung District, Sumedang Regency, West Java Province. Learning screen printing that has been taught consists of basic understanding of visual communication design, making film image designs to the process of making film afdruk and screen printing processes using paper and cloth media [1].

This activity is in order to help the community to create new business opportunities due to the impact of the Covid-19 pandemic, which has caused most people in this region to lose their permanent jobs. This can be exemplified by some of the Puteraco community who have out of a job from their place of work due to the closure of the company, there are also casual daily workers who rely on work as laborers and construction workers, there is no job opportunity due to government regulations that appeal to the public to stay at home in order to avoid the dangers of the covid-19 pandemic and maintain health $[2,3]$.
Based on the explanation above, it is deemed necessary that this screen print learning be used as a learning model for the community as research-based service carried out by the higher education institutions of Universitas Pendidikan Indonesia to contribute to the field of community economic development through filter print learning [4].

In its implementation, this activity is carried out with a blended learning system, the aim is to provide convenience to participants in the learning process carried out. So that people, even though they live at home, can still carry out activities in order to learn skills to fill in the blanks of time and try new alternatives in order to open up independent business opportunities [5].

\section{THEORIZATION}

Learning design is a process of teaching development through the practice of composing communication technology media and content to help ensure effective transfer of knowledge between teachers and students and to ensure the quality of learning, according to Syaiful Sagala [6].

Learning screen print is one approach that can be done to the community in the context of being a burnout therapy due to staying at home a lot and being given new insights in order to increase work skills. This activity can be done alone or in groups, so it is not too difficult to arrange a place and maintain health protocols in the learning process.

The hope is that through this learning, it is hoped that the community will have new business opportunities that can build their family's economy, through new business opportunities in the screen print creative industry. The learning approach used is a collaborative learning approach with the aim that participants can be responsible for their own learning and try to find answers to the learning they get. The task of the researcher as a facilitator provides motivation to provide freedom of learning, with the hope that the results obtained vary according to the wishes of the training participants. As for the forms of peer-assessment as an assessment of fellow participants, it is 
used to see to what extent the results of the participants have mastered the material that has been taught.

\section{Methodology}

The research-based service approach used is descriptive qualitative, namely an innovative practical approach that describes real and natural symptoms. It is necessary to use an experimental method in the form of design development to achieve the goal, namely leading to the ability to print on paper and cloth media through the screen printing technique process.

The population of this research is the people in the village of Pasirnanjung, Cimanggung District, Sumedang Regency, while the sample or target of the research is the creative community who resides in Perum Putraco RW 03 Pasirnanjung Village.

The researcher refers to the $R \& D$ steps by taking two stages, namely a preliminary study and testing. The first stage, in the form of a preliminary study conducted by using document study techniques, observation and interviews. The results of the preliminary study found the development of learning forms. The second stage is the implementation of the screen print learning form [7].

The preliminary study was carried out in three steps, namely literature study, field survey, and preparation of the initial product. Document studies are conducted to study the relevant theories and concepts for the screen print learning process that will be developed. The important documents required are in the form of a schedule, preparation and practice of screen print learning. Field studies or surveys were carried out to collect data regarding the planning and implementation of screen printing learning in the Putraco RW 03 Pasirnanjung Village community. Data were collected by means of observation, interviews, during the implementation of learning. The data collected includes community learning activities and the screen print process that has been carried out.

Aspects of data collected include, the results of making images for making designs or the form of images to be printed, the process of making affdruk film and the process when learning to screen print and the results that have been obtained. Referring to the results of observations during the learning process, the researcher compiled a draft of the initial product which was then reviewed in a limited group meeting and discussion in the form of a Focus Group Discussion (FGD). The results of the FGD in the form of input are taken into consideration for the draft of product results that can be improved.

The final learning stage in this first year carried out the method of testing the ability to draw films, the film printing process and the screen printing process which were implemented in the learning of making screen print products.

\section{RESEARCH RESULTS}

This research-based community service in Pasirnanjung Village has provided knowledge for the community in the field of screen print skills and produced samples of screen print products, although they are still simple in nature but have shown a fairly good learning ability and can be further improved as learning that refers to art creative industry that has a selling value and can be an incubation model for the local community.

The following are forms of screen print learning activities that have been carried out in the Putraco RW 03 Desa Pasirnanjung Village, Cimanggung District, Sumedang Regency:

\section{A. Preparation and Discussion about Screen Print Learning}

Preparation for this activity discusses the similarity of perceptions and procedures for learning preparation for screen print and the introduction of screen print tools and materials adapted for the basic level for the community to make it easier for participants to follow the learning process, so that it is easy to understand and master the screen print technique [8] (see figure 1)

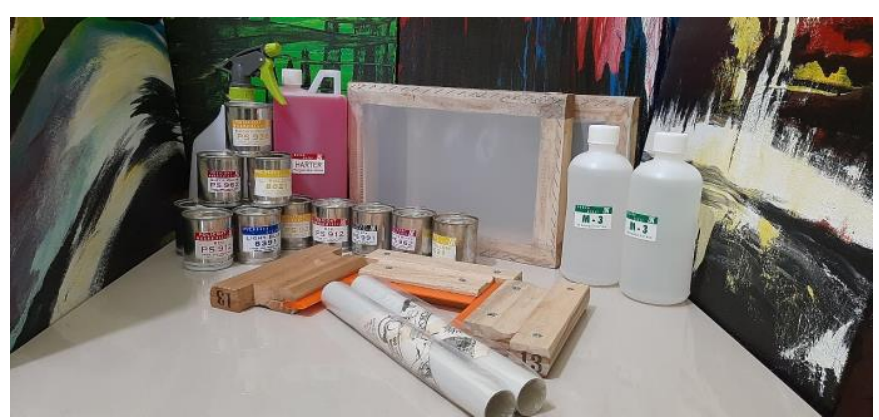

Fig. 1. The main equipment needed for screen printing.

\section{B. Filming Base}

In this basic film-making material, participants are directed to imitate an existing image which is then copied or replicated using tracing paper and the next destination for the image that has been transferred to tracing paper is called film image (see figure 2). 


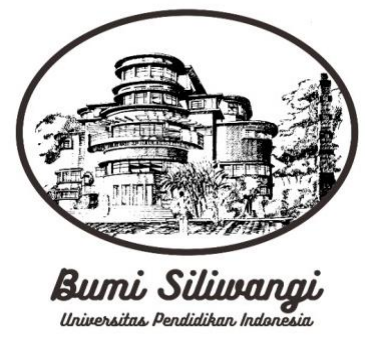

Fig. 2. The process of making film images from HVS paper is transferred to tracing paper

\section{Afdruk Film-Making Process}

One of the processes that must be done before doing screen printing is to make a screen printing film, the way to provide an elmution drug on the screen printing cloth which functions to bind the monyl cloth to block the incoming ink, while the film drawing is part of the area that can be penetrated by ink due to the film emulsion process that done by shining a lamp or the sun (see figure 3 ).

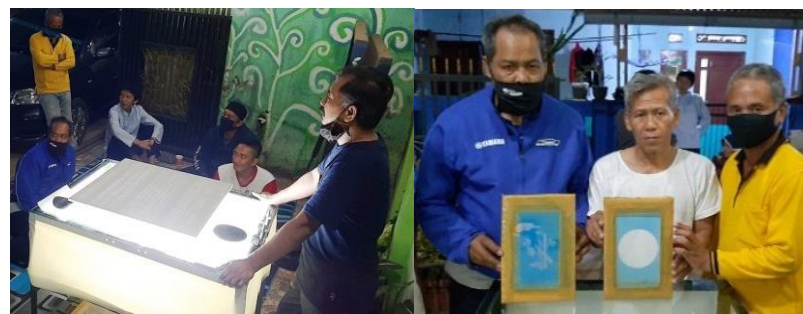

Fig. 3. The process of making afdruk film from tracing paper is transferred to monyl fabric / screen printing as a step before printing.

\section{Process screen print with paper media}

The first introduction to the printing process was carried out by the leader of the research team, about how to use screen printing techniques that were easy and fun as skills knowledge through HVS paper material [9] (see figure 4).

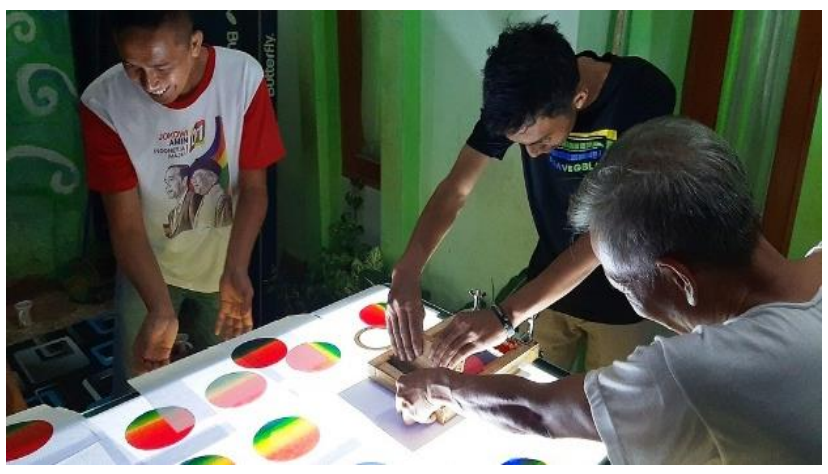

Fig. 4. The printing process uses HVS paper material.

\section{E. Screen Print Process with Cloth Media Material}

The first introduction to the printing process was carried out by the head of the research team, about how to filter printing techniques that are easy and fun as skill knowledge through cotton fabric for t-shirts. This trial uses the ready-made to provide experience for participants to understand different media $[10,11]$ (see figure 5).

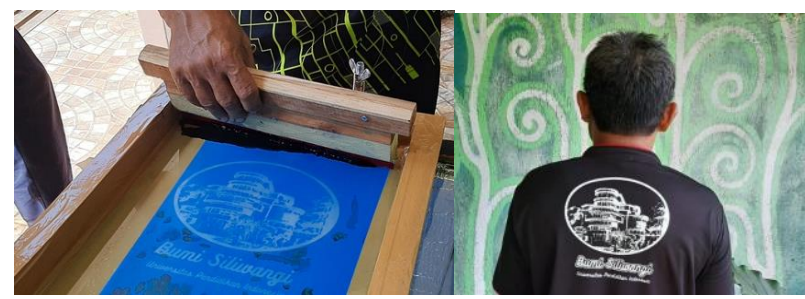

Fig. 5. The printing process uses cotton fabric.

\section{CONCLUSION}

The learning of the screen print creative industry for the people of Putraco RW 03 Pasirnanjung Village has an influence on public awareness to develop training techniques which are marked by the enthusiasm of the community and a shared commitment to mutual learning and mutual empowerment among the community. The innovative learning innovation space with AFG has been able to shape the concept of community education based on the screen-printing creative industry learning. In addition to new innovations, new methods were also found in order to prepare themselves for the economic development of the creative industry that originated from community independence.

Although the results obtained in this first year are still in the form of basic learning and understanding of screen printing techniques using paper and cloth media. The goal is for the community in this first year to really master the material of screen printing techniques, so that in the second year the learning can increase in learning screen printing which can foster an entrepreneurial spirit and independence for the residents of the surrounding community.

In this case, the LPPM UPI institution is expected to facilitate activities in the second year stage. So that in the second year of service, it is hoped that this accelerator can develop programs with researchers through screen print learning and mentoring in creative screen print creative products, whose activities are carried out more towards further learning, which further learning has led to the selling value of the product to be produced.

\section{REFERENCES}

[1] A. Kusrianto, Pengantar Desain komunikasi Visual, Yogyakarta: Andi. 2009.

[2] G.G. Meredith et al., Kewirausahaan, Teori dan Praktek. Jakarta: PPM. 2002

[3] M. Tohar, Membuka Usaha Kecil. Yogyakarta: Kanisius. 2000 
[4] T. Soekamto, and Winaputra, Teori Belajar dan Model-Model Pembelajaran. Jakarta: Pusat Antar Universitas Direktorat Jenderal Pendidikan Tinggi Departemen Pendidikan dan Kebudayaan. 1997.

[5] T. Soekamto and Winaputra, Teori Belajar dan Model-Model Pembelajaran. Jakarta: Pusat Antar Universitas Direktorat Jenderal Pendidikan Tinggi Departemen Pendidikan dan Kebudayaan. 1997.

[6] S. Sagala, Konsep dan Makna Pembelajaran Untuk Membantu Memecahkan Problematika Belajar dan Mengajar. Bandung: Alfabet. 2005.

[7] N.S. Sukmadinata, Metode Penelitian Pendidikan; penelitian memberikan deskripsi, eksplanasi, prediksi, inovasi, dan juga dasar- dasar teoritis bagi pengembangan pendidikan. Bandung: Remaja Rosdakarya. 2011.

[8] A. Asmara, Panduan Lengkap Cetak Sablon, Jakarta: Titian Ilmu. 2010.

[9] M.F. Andrews, Creative Printmaking. New Jersey: Prentice-Hall, Inc. 1964.

[10] M.I. Tobroni, "Teknik Sablon sebagai Media Apresiasi Karya Desain pada Tshirt". Humaniora, 2 (1), 169-181. 2011.

[11] D. Cahyadi, "Developing Skills Through Print Packaging Screen Printing", Tanra Vol 6, No 2. 2019. 